\title{
Chapter 8 \\ Conflict and Livelihood Decisions in the Chittagong Hill Tracts of Bangladesh
}

\author{
Muhammad Badiuzzaman and Syed Mansoob Murshed
}

\begin{abstract}
We analyse rural household livelihood and child school enrolment decisions in the post-conflict setting of the Chittagong Hill Tracts (CHT) region of Bangladesh. What makes this paper innovative is the use of current subjective perceptions regarding the possibility of violence in the future and past actual experiences of violence in explaining household economic decision-making. Preferences are endogenous in line with behavioural economics. Regression results show that heightened subjective perceptions of future violence and past actual experiences of conflict influence current consumption and child enrolment and could encourage risky mixed crop cultivation. The trauma emanating from past experiences combined with current high perceptions of risk of violence may induce bolder and riskier behaviour in line with prospect theories of risk. Furthermore, a postconflict household-level Phoenix or economic revival factor may be in operation, based partially on greater within-group trust.
\end{abstract}

Keywords Perceptions of violence $\cdot$ Post-conflict reconstruction $\cdot$ Risk $\cdot$ Livelihood decision-making

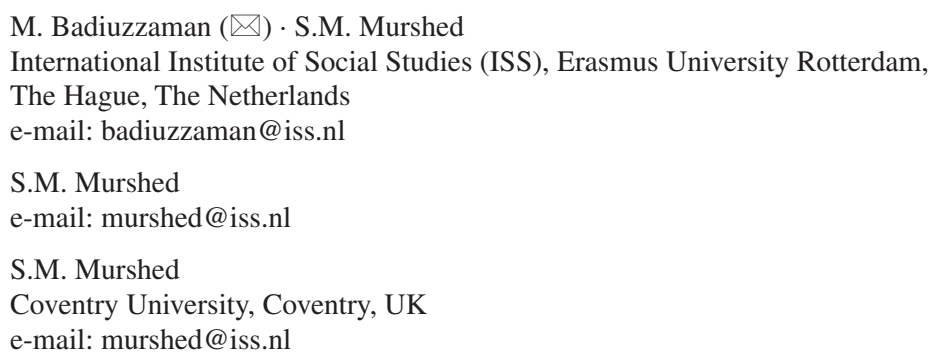




\subsection{Introduction}

The object of this paper is to analyse rural household livelihood decisions, including educational investment for future generations, in the post-conflict setting of the Chittagong Hill Tracts (CHT) region of Bangladesh. This is a region in the southeastern part of the country where a low-level insurgency took place between 1976 and 1997, officially terminating after a peace accord in December, 1997. ${ }^{1}$ The armed struggle was between the state's security forces, mainly the Bangladesh army, and the ethnically distinct local population (indigenous), in an otherwise fairly homogenous nation in terms of language and religion. The insurgency was aimed at regional autonomy rather than independence, but the principal local grievance was against officially sponsored land encroachment and grabbing by outsiders (Bengali population) who posed a threat to not only local livelihoods but also a distinct local way of life; see Chakma (2006) and Roy (2000). This happened in the land-hungry context of the world's most densely populated country, which is also a low-income developing country where agriculture continues to be the main source of the population's livelihood. Thus, while neo-Malthusian factors may be at work, land hunger is principally caused by poverty and the paucity of alternative livelihoods to agriculture. Population growth adds to land scarcity, exacerbated by environmental degradation, fuelling conflict over land and environmental resources (Homer-Dixon 1999), as is the case in the CHT between the indigenous population and settler Bengalis.

There is now a substantial literature on the causes of large-scale internal conflict in the rational choice tradition. These explanations tend to centre on either the grievance hypothesis (mainly linked to inequalities between distinct groups delineated by ethnicity, religion, or some other marker) or the greed motivation (reflecting competition over capturable rents); see Murshed (2010, Chap. 3) for a review. A great deal of empirical work has also been conducted to test the empirical validity of these allegedly competing theories. The results are inconclusive, mainly due to data paucity on inter-group inequality (also known as horizontal inequality). Be that as it may, there is a consensus that violent internal conflict serves to perpetuate poverty in developing countries, and equally, poverty increases the risk of violent conflict breaking out. This is referred to as the conflict-poverty trap; see Collier (2007).

Many of the quantitative studies on civil war are cross-country in nature, where the experiences of civil war in different and far-flung countries are lumped together in one single statistical (econometric) exercise. One can, therefore, be sceptical about the results of such regression analyses, as the various conflicts under scrutiny are not necessarily drawn from a homogenous population. There

\footnotetext{
1 The conflict in the CHT of Bangladesh is coded as a minor armed conflict, according to the PRIO-Uppsala methodology; see http://www.prio.no/CSCW/Datasets/Armed-Conflict/UCDPPRIO/Armed-Conflicts-Version-X-2009/ (accessed November 05, 2010).
} 
is also a need to conduct more systematic quantitative studies of the drivers and consequences of conflict at a more local level within nation states, a research area that is still relatively neglected.

Armed conflict may have far-reaching consequences for rural livelihood strategies, including investment decisions and cropping patterns. This may contribute to an analysis of poverty as well as development in general, particularly rural development. Lacunae associated with localised conflict become even more acute when it comes to the economic analyses of the short- and long-term impacts of conflict on households' decision-making. The first innovation of this paper is that it is able to make a contribution in this connection based on a unique data set compiled during a socio-economic survey of households in this area in 2008 (Barkat et al. 2009).

The rural farming household is no stranger to risky outlays, as returns to cropping or animal husbandry are subject to a number of risks and uncertainties. We will utilise the livelihood framework to explain household decisions under uncertainty. This approach acknowledges an inherent inseparability between production and consumption decisions for rural households (Bardhan and Udry 1999, Chap. 2), which affects labour allocation between farm and off-farm (including education) activities, as well as cropping (and animal husbandry activities) for own consumption and the market.

The nature of these risks and uncertainties can be altered by armed conflict of a sufficiently long duration. This affects the livelihood and investment decisions of households. We will relate our findings to prospect theory (Kahneman and Tversky 1979) to explain greater risk-taking behaviour following the traumas of war, where a strong desire to retrieve a valued past state may help explain increased risk-taking. This is the second innovation of the paper. Additionally, the survey employed in the paper contains information about subjective perceptions regarding the future prospects of violence after the conflict ended as well as past actual experiences of violence, both of which impact household economic decision-making. Thus, we are dealing with preferences that are endogenous to not only economic, political and social institutions (Bowles 1998; Fehr and Hoff 2011) but also personal histories of trauma and expectations of future conflict. Along with standard socioeconomic characteristics, our household survey data contain both subjective (psychological) information regarding trust, current perceptions about the risk of future conflict and objective data on past conflict experience. We relate these to observed livelihood decision-making. This is in line with contemporary behavioural economics as well as earlier thinking (for instance, Boulding 1956), about individual self-image and the effect of various stimuli in framing one's image.

Our analysis is conducted in the post-accord era, a decade after the peace treaty which allegedly ended the war. An important policy consideration in postconflict societies is the resumption of economic activity and growth. On the one hand, post-conflict growth can be lopsided, favouring infrastructure reconstruction over agriculture or manufacturing, due to wartime collateral damage as well as the perceived riskiness of investment in productive sectors which take a long time to 
yield dividends (Addison and Murshed 2005). On the other hand, other authors emphasise a more general 'Phoenix' factor (Koubi 2005). In other words, rapid economic growth (in the macroeconomic sense) follows the cessation of intense and prolonged conflict, resembling the fable of the Phoenix rising from the ashes. There can, however, be differences across various economic sectors. Our third innovation is that we examine whether there can be such a local Phoenix factor given the impact of subjective perceptions on household cropping decisions.

\subsection{The Chittagong Hill Tracts of Bangladesh}

Bangladesh is in the Ganges delta and is one of the most densely $\left(1,229 / \mathrm{km}^{2}\right)$ populated countries in the world where the amount of per capita arable land was only 0.1 ha in 2007. It is a low-income developing country, where about $50 \%$ of the population lives in poverty (using the international poverty line of below $\$ 1.25$ per day; World Bank 2010). Over the last two decades, Bangladesh's economy experienced growth rates of around $5.5 \%$ per annum, but a large segment of employment still relates to traditional agriculture (World development indicators, The World Bank, Washington DC http://data.worldbank.org/indicator/ NY.GDP.MKTP.KD.ZG, Accessed 11 Jan 2011). This makes land the scarcest and most competed over resource in Bangladesh. Land issues have been seen to underpin a variety of Maoist uprisings in neighbouring India and Nepal, and the literature on these is copious; for example, Murshed and Gates (2005) find a statistically significant relationship between conflict intensity (district-wise fatalities) and landlessness in the context of the Maoist insurgency in Nepal. Few studies, however, have a similar methodology to the one in this paper based upon detailed household surveys, and household level responses to risk and uncertainty in a post-conflict setting.

Bangladesh is mostly ethnically homogenous, with the vast majority of the population being Bengali speaking and Muslim. There are a few distinct ethnicities that differ in both language and religion. These groups are mainly concentrated in the CHT region. This region is situated in the south-eastern part of the country and is covered with lush green hills, with a relatively larger proportion of afforested areas. From a strategic point of view, CHT is important as it adjoins two Indian states (Tripura and Mizoram) and Myanmar. Insurgency in the Indian north-eastern states and Myanmar raises the military importance of this region (Roy 2000; Barkat et al. 2009; Mohsin 2003). The various ethnic groups in CHT are closer, in appearance and culture, to their neighbours in north-eastern India, Myanmar and Thailand, than to the rest of Bangladesh. Buddhism, Hinduism and Christianity are prevalent among these ethnicities. They have their own languages in both oral and written form. The indigenous peoples of CHT are often identified as Jumma people, derived from the word jum (swidden or slash and burn shifting cultivation). The proportion of the non-indigenous (Bengali speaking) population in CHT has been increasing over time. According to the 
1991 population census of Bangladesh, indigenous groups constitute $51.4 \%$ of the CHT total population of about one million (Mohsin 2003; Roy 2000). It is important to note that the indigenous inhabitants of CHT also exhibit a degree of diversity based on eleven different (tribal) identities.

Despite its lower population density compared to the rest of Bangladesh, the CHT region is actually land-scarce in terms of availability of land for cultivation (only $23 \%$ of the land is arable). In 1974, the amount of per capita arable land was about 0.45 ha, which declined to about 0.24 ha in 1991. Most of the land is either uninhabitable due to its topography or its usage is restricted by law (reserve or protected forests). The land ownership patterns as well as types of land in CHT also differ from that of plain regions. Customary (common) ownership of land exists here, and at the same time, private property rights are recognised by the state, making ownership issues more complex (Roy 2000; Barkat et al. 2009).

The CHT region enjoyed an autonomous status until 1860 when the British took it over under their direct administration. The CHT regulation of 1900 put an embargo on 'outsiders' settling or purchasing land in the territory. This 'excluded area' status of CHT was replaced by a 'tribal area' classification in $1962 .{ }^{2}$ Due to the construction of an artificial reservoir by damming the River Karnafuli at Kaptai in the 1960s for the purposes of power generation, approximately $1,036 \mathrm{~km}^{2}$ was submerged and 54,000 acres of highly prized arable land was lost in the river valleys. After the independence of Bangladesh from Pakistan in 1971, the indigenous people of CHT demanded recognition of their ethnic identity and regional autonomy in the constitution, which has not happened. Given the population transfer policies of non-indigenous people into this region by successive Bangladesh governments, the demand for indigenous rights transformed into armed rebellion by different indigenous groups.

Successive Bangladeshi governments of both a military and democratic complexion adopted mixed strategies of using military force to quell rebellion, while, at the same time, encouraging, or colluding with, a population transfer programme. In 1976, armed forces were deployed in CHT in a classic 'Aid to Civil Power' operation, which triggered tensions in the region. A few indigenous political groups [Parbatya Chattagram Jana Samhiti Samiti (PCJSS)] engaged in an armed insurgency against the intrusion by the authorities. Under the counterinsurgency strategy, demographic engineering interventions aimed at settling a large number of Bengali-speaking households in CHT were seen as enhancing the size of population loyal to the state, and these fresh settlements acted as a counterweight to indigenous peoples' demands for rights and regional autonomy. Due to the state-sponsored settlement programme, a considerable number of indigenous people were uprooted from their homesteads, further intensifying the armed

\footnotetext{
2 A well-known paper by Banerjee and Iyer (2005) relates colonial land tenure systems in India to agriculture productivity, demonstrating lower productivity in areas where landlordism prevailed compared to regions where the state directly taxed the peasant farmer. In our case, the colonial period legacy is one of landlordism.
} 
struggle. About 54,000 indigenous people took refuge in the neighbouring Tripura state of India and another 50,000 became internally displaced persons.

In the post-cold war era, and after the restoration of democracy in Bangladesh, pressure for a political solution mounted. This led to an accord between the PCJSS and the Bangladesh Government on 2 December 1997, known as 'The CHT accord 1997'. The accord was incomplete; the United Peoples Democratic Front (UPDF) continues the struggle for full autonomy (Mohsin 2003). Continuing land disputes, the non-restitution of land to indigenous peoples, the presence of the Bangladesh army, the poor rehabilitation of refugees and internally displaced persons, and the non-implementation of a special status in the country's constitution make the post-conflict situation of CHT fragile. Indigenous people living in this area continue experiencing various types of violence and face restrictions on their mobility (Barkat et al. 2009).

\subsection{Data and Methodology}

The 'Socio-economic Baseline Survey of CHT' is the source of our quantitative data; see Barkat et al. (2009). The data were collected in 2008 from a cross section of households (both migrant Bengalis and indigenous people) living in CHT. The sample design of the survey captured the whole region of CHT, especially the ethnic diversity among the indigenous population. The representative sample is comprised of 3,238 households, where the number of indigenous and migrant Bengali households was 1,786 and 1,452, respectively. Although the main focus of the survey was collecting data on the socio-economic status of the CHT population, it also gathered information on peace-confidence building issues. In particular, what is noteworthy is that data on current post-conflict subjective perceptions about the degree of violence, and the chance of its occurring in future, were collected from households for the year 2008. These pertain to their threat perceptions about the extent of armed conflict, the possibility of attacks from the other community, the fear of forcible eviction as well as other variables at the time of the survey. These variables amount to expectations about the future prospects of conflict.

In addition, data on households' actual experience of violence, or their participation in conflict, during the years of the insurgency (1976-1997) were also collected. These refer to past experiences of violence and were related to displacement or eviction, loss of land and armed conflict, among others. Not surprisingly, there are missing observations, both at the level of perception and in the actual past experiences of conflict, as not all households were able to reveal this sensitive information, not least because of the continued presence of the Bangladesh army in this area. Furthermore, we have data on the degree of trust (social capital) between the two communities, including between the different tribes that make up the indigenous segment of the population in CHT. 


\subsubsection{Descriptive Statistics}

Perceptual data on the threat of violence pertain to the year of the survey (2008). This allows the researcher to analyse the nexus between perceptions of violence and various livelihood decisions in a post-conflict setting. In Table 8.1, perceptions about the threat of violence relate to three variables: (i) perceptions about armed conflict, (ii) perceptions about communal violence occurring and (iii) the fear of eviction. In the survey, 14-16\% households perceived a threat of armed conflict, while a third (32-34\%) felt a danger of communal violence, and 37-38\% of households were apprehensive about possible eviction from their land.

Data on real-life experiences of conflict for the period of the insurgency (19761997) were collected from households (with at least one family member experiencing violence) chiefly in the form of three broad categories: (i) displacement from home, (ii) dispossession of land (either farmland or homestead) and (iii) participation in and/or victim of armed conflict; see Table 8.1. Estimates indicate that $13-14 \%$ of the households experienced displacement from their own home or land and 18-20\% were dispossessed of their farmland before the peace accord in 1997. All in all, various types of armed conflict were experienced by 17-20\% of the households.

Additionally, some $91 \%$ of indigenous households felt that their group relations were good, implying the presence of trust within the eleven different tribes which comprise the community. It has to be borne in mind that the indigenous peoples' antagonists (settler Bengalis) are ethnically homogenous, and we would expect a high level of trust within that group. Only about $11 \%$ of the responses pointed to good relations between the settler and indigenous communities.

Three household livelihood decisions - consumption expenditure, decisions with regard to children's schooling and production (cropping) decisions-were analysed. Data on consumption incorporated a separate format for food and non-food expenditure (Table 8.1). We may regard the decision to enrol children in school as an investment (human capital accumulating) decision. Data on total number of children enrolled in both primary and secondary school were analysed at the household level, within the age bracket of 6-18 years. Estimates show that $44 \%$ children of the CHT were enrolled in schools. The type of crop produced is a proxy for production decisions. Some $42-43 \%$ of households produced only food crops, an insignificantly small proportion of households produced only cash crops, and there were a good number of households (50-51\%) producing both cash and food crops.

\subsubsection{Empirical Model Specification and Strategy}

Our quantitative analysis primarily focuses on the relation between either the perceived threat of violence after the peace accord or the past experience of conflict before the peace accord on various livelihood decision-making by households 
Table 8.1 Descriptive statistics: conflict and livelihood

\begin{tabular}{|c|c|c|c|c|c|c|}
\hline \multirow[t]{2}{*}{ Variables } & \multicolumn{3}{|c|}{ Indigenous household } & \multicolumn{3}{|c|}{ Bengali household } \\
\hline & Mean & $\begin{array}{l}\text { Standard } \\
\text { deviation }\end{array}$ & \begin{tabular}{|l} 
Number of \\
observations
\end{tabular} & Mean & $\begin{array}{l}\text { Standard } \\
\text { deviation }\end{array}$ & $\begin{array}{l}\text { Number of } \\
\text { observations }\end{array}$ \\
\hline \multicolumn{7}{|c|}{ Current perception of violence } \\
\hline $\begin{array}{l}\text { Fear of armed } \\
\text { conflict }\end{array}$ & 0.16 & 0.3709 & 1,786 & 0.14 & 0.3498 & 1,367 \\
\hline $\begin{array}{l}\text { Fear of communal } \\
\text { violence }\end{array}$ & 0.32 & 0.4680 & 1,786 & 0.34 & 0.4741 & 1,367 \\
\hline $\begin{array}{l}\text { Fear of eviction } \\
\text { from land }\end{array}$ & 0.38 & 0.4847 & 1,786 & 0.37 & 0.4845 & 1,367 \\
\hline \multicolumn{7}{|c|}{ Previous experience of violence } \\
\hline Displacement & 0.13 & 0.3320 & 1,786 & 0.14 & 0.3483 & 1,367 \\
\hline Land dispossession & 0.18 & 0.3830 & 1,786 & 0.20 & 0.3988 & 1,367 \\
\hline Armed conflict & 0.20 & 0.4016 & 1,786 & 0.17 & 0.3787 & 1,367 \\
\hline Social capital & 0.91 & 0.2795 & 1,183 & 0.11 & 0.3160 & 881 \\
\hline \multicolumn{7}{|c|}{ Consumption decision } \\
\hline $\begin{array}{l}\text { Per capita annual } \\
\text { consumption } \\
\text { expenditure (in Tk.) }\end{array}$ & 11,857 & $4,331.67$ & 1,786 & 11,862 & $4,731.07$ & 1,452 \\
\hline $\begin{array}{l}\text { Per capita annual } \\
\text { food consumption } \\
\text { expenditure (in Tk.) }\end{array}$ & 11,095 & $4,152.20$ & 1,786 & 11,113 & $4,535.11$ & 1,452 \\
\hline $\begin{array}{l}\text { Per capita annual } \\
\text { non-food consump- } \\
\text { tion expenditure } \\
\text { (in Tk.) }\end{array}$ & 762 & 445.07 & 1,786 & 749 & 409.15 & 1,452 \\
\hline \multicolumn{7}{|l|}{ Investment decision } \\
\hline $\begin{array}{l}\text { Child enrolment } \\
\text { in primary and } \\
\text { secondary school }\end{array}$ & 0.44 & 0.4961 & 2,345 & 0.44 & 0.4965 & 1,625 \\
\hline \multicolumn{7}{|c|}{ Production decision: type of cropping } \\
\hline Only food crop & 0.43 & 0.4952 & 1,206 & 0.42 & 0.4946 & 899 \\
\hline Only cash crop & 0.07 & 0.2574 & 1,206 & 0.06 & 0.2397 & 899 \\
\hline $\begin{array}{l}\text { Mixed crop (both } \\
\text { food and cash) }\end{array}$ & 0.50 & 0.5002 & 1,206 & 0.51 & 0.5001 & 899 \\
\hline
\end{tabular}

living in the $\mathrm{CHT}^{3}$ For consumption decisions, an OLS model was used. But for investment in children's education and production (cropping) decisions, a logit or probit model was specified, as these two cases measure the probability or chance of an event occurring. We control for household demographic and socio-economic characteristics including those for children, type of school, facilities at the school and agricultural techniques.

${ }^{3}$ Full details of the estimations, as well as the descriptive statistics, can be found in Badiuzzaman et al. (2013). 
The standard regression equation followed in this paper is as follows:

$$
Y_{i}=\alpha+\beta_{1} \mathrm{HSE}_{i j}+\beta_{2} H_{i j}+\beta_{3} C_{i j}+\beta_{4} S_{i j}+\beta_{5}\left(V_{i j}, \mathrm{PV}_{i j}, \mathrm{SC}_{i j *} \mathrm{PV}_{i j}\right)+\varepsilon_{i},
$$

where the dependent variable $Y_{i}$ refers to various livelihood decision-making variables, consisting of consumption expenditure (continuous variable in logarithmic form), child enrolment in either primary or secondary school (dummy variable), and type of crop produced (dummy variable) for household $i$ measured at the survey. The explanatory variables are as follows: $\mathrm{HSE}_{i j}$ are household-level demographic and socio-economic variables, $C_{i j}$ is a set of child characteristics (age and sex), $H_{i j}$ describes household head characteristics (age, sex and education), $S_{i j}$ denotes schooling variables, $\mathrm{SC}_{i j}$ indicates social capital or trust, $V_{i j}$ stands for threat perceptions at the time of the survey, $\mathrm{PV}_{i j}$ indicates pre-peace accord experiences of violence, and $\varepsilon_{i}$ is a random error term.

Moreover, we use interaction variables for experiences of violence along with trust in three regression models. Trust (social capital) is not entered as a separate explanatory variable as current perceptions of violence approximate the converse of between-group (indigenous versus settler) social capital. Trust between the various (11) indigenous ethnicities is more relevant and constitutes a key factor in how the impact of previous experiences of violence has evolved into present-day decision-making and preferences. Hence, we only use trust as an interaction term with past conflict experience. For Bengalis, the social capital variable reflects trust between indigenous and Bengali peoples, while for the indigenous people, it is trust between the eleven indigenous tribal groups.

\subsection{Results and Discussions}

This section analyses the determinants of household consumption decisions, followed by two other important livelihood decisions-investment in children's education and cropping (production) decisions-in relation to subjective perceptions of varying degrees of the threat of violence, within indigenous group trust factors and pre-peace accord experiences of violence. We believe this to be a major innovation of our study because we attempt to gauge the impact of subjective perceptions on economic decision-making with regard to consumption, output (cropping) and investment decisions after an uneasy peace accord that only imperfectly ended the conflict. Within the context we are studying, land dispossession is a key factor, and the continuing fear of intimidation with a view to further land alienation is likely to impact on indigenous households' decision-making under uncertainty. To this end, and to sharpen our focus and analysis, we classify individual households' fears of future violence into different variables: armed conflict, communal violence and fear of eviction from land. 


\subsubsection{Consumption Expenditure}

We endogenise preferences about consumption to past conflict experiences and expectations about future conflict. We do this separately for the indigenous people and settler Bengalis (Table 8.2). Specification 1 relates to current perceptions about violence. Among these, the fear of armed conflict negatively and significantly affects consumption, both food and non-food, for both indigenous and Bengali peoples. The fear of communal violence is less significant. It adversely effects non-food consumption for both communities. As far as the fear of eviction is concerned, it significantly raises consumption for Bengali settlers, but not for the indigenous inhabitants of CHT, although the signs are in a positive direction.

It may be argued that there are endogeneity issues between current perceptions of violence and consumption because households with greater economic capacity may feel more threatened. To get consistent coefficient estimates for consumption expenditure regression, we attempted a two-stage least squares (2SLS) estimation approach where at the first stage we require instrumental variables. There are a few variables in our data set that are potential candidates for instruments. For overall consumption and food consumption regressions, we used three variables: good relationship between Bengali and indigenous communities, perceptions about the oppressiveness of the security forces and previous land dispossession which are uncorrelated with consumption, but correlated with our three variables of interest under current perceptions of violence. For non-food consumption, we used three variables: satisfaction about inter-community interaction, attendance in the other group's festivals and festivals celebrated jointly which are effective instruments. Results from 2SLS estimates found current perceptions of violence insignificant in determining overall consumption expenditure, and for food and non-food consumption separately. However, since alternative Hausman tests of exogeneity indicate no endogeneity between current perceptions of violence and consumption expenditure, when we compare OLS and 2SLS estimates, we can be confident about the reliability of our OLS estimates. Details may be found in Badiuzzaman et al. (2013).

The regression results under specification 2 relate to past experiences of violence. Displacement discouraged consumption, but significantly only for Bengali settlers. Land dispossession encouraged non-food consumption significantly for both communities. Personal experiences of armed conflict (in the past) discourage consumption, but more strongly for Bengali settlers.

We also attempted to investigate the role of trust (social capital) in the form of good relations among the various indigenous communities on consumption (specification 3, in Table 8.2). Arguably, intra-group trust has an important role on livelihoods in post-conflict settings, especially for the indigenous inhabitants of the region. Accordingly, we interacted three variables on previous experiences of violence: displacement, land dispossession and actual experiences of armed conflict with current good relations among the indigenous communities (trust) as a proxy of social capital. Specification 3 indicates that among the three interaction 
Table 8.2 Determinant of consumption expenditure: OLS estimation

\begin{tabular}{|c|c|c|c|}
\hline \multirow[t]{2}{*}{ Independent variable } & \multicolumn{3}{|l|}{ Dependent variable } \\
\hline & $\begin{array}{l}\text { All consumption } \\
\text { expenditure }\end{array}$ & $\begin{array}{l}\text { Food consumption } \\
\text { expenditure }\end{array}$ & $\begin{array}{l}\text { Non-food consump- } \\
\text { tion expenditure }\end{array}$ \\
\hline \multicolumn{4}{|c|}{ Indigenous household } \\
\hline \multicolumn{4}{|c|}{ Specification 1: Current perception of violence } \\
\hline Fear of armed conflict & $-0.07 * * *(0.025)$ & $-0.07 * * *(0.026)$ & $-0.13 * * *(0.033)$ \\
\hline $\begin{array}{l}\text { Fear of communal } \\
\text { violence }\end{array}$ & $0.03(0.025)$ & $0.04(0.026)$ & $-0.06^{*}(0.034)$ \\
\hline $\begin{array}{l}\text { Fear of eviction from } \\
\text { land }\end{array}$ & $0.03(0.026)$ & $0.03(0.027)$ & $0.05(0.03)$ \\
\hline \multicolumn{4}{|c|}{ Specification 2: Previous experience of violence } \\
\hline Displacement & $-0.03(0.037)$ & $-0.04(0.034)$ & $0.03(0.039)$ \\
\hline Land dispossession & $-0.03(0.023)$ & $-0.04 *(0.024)$ & $0.06^{*}(0.035)$ \\
\hline Past armed conflict & $-0.005(0.022)$ & $0.01(0.023)$ & $-0.13 * * *(0.033)$ \\
\hline \multicolumn{4}{|c|}{ Specification 3: Interaction of previous experience of violence and social capital } \\
\hline Displacement $*$ trust & $-0.09(0.096)$ & $-0.097(0.0982)$ & $-0.035(0.148)$ \\
\hline $\begin{array}{l}\text { Land dispossession* } \\
\text { trust }\end{array}$ & $0.10(0.076)$ & $0.092(0.0780)$ & $0.19 * *(0.143)$ \\
\hline $\begin{array}{l}\text { Past armed conflict* } \\
\text { trust }\end{array}$ & $0.11 * * *(0.084)$ & $0.12 * * *(0.084)$ & $-0.10(0.130)$ \\
\hline
\end{tabular}

\section{Bengali household}

\begin{tabular}{l|l|l|l}
\hline \multicolumn{3}{l}{ Specification 1: Current perception of violence } \\
\hline Fear of armed conflict & $-0.16 * * *(0.040)$ & $-0.16 * * *(0.041)$ & $-0.135 * * *(0.0433)$ \\
\hline $\begin{array}{l}\text { Fear of communal } \\
\text { violence }\end{array}$ & $0.01(0.033)$ & $0.02(0.034)$ & $-0.101 * *(0.0393)$ \\
\hline $\begin{array}{l}\text { Fear of eviction from } \\
\text { land }\end{array}$ & $0.07 * *(0.035)$ & $0.07 *(0.037)$ & $0.07 *(0.041)$ \\
\hline
\end{tabular}

Specification 2: Previous experience of violence

\begin{tabular}{l|l|l|l}
\hline Displacement & $-0.08 * *(0.039)$ & $-0.087 * *(0.0412)$ & $-0.02(0.045)$ \\
\hline Land dispossession & $0.04(0.028)$ & $0.040(0.0289)$ & $0.07 *(0.039)$ \\
\hline Past armed conflict & $-0.10 * * *(0.030)$ & $-0.09 * * *(0.031)$ & $-0.14 * * *(0.039)$
\end{tabular}

Specification 3: Interaction of previous experience of violence and social capital

\begin{tabular}{l|l|l|l}
\hline Displacement* trust & $0.09(0.143)$ & $0.10(0.1558)$ & $-0.05(0.1395)$ \\
\hline $\begin{array}{l}\text { Land dispossession* } \\
\text { trust }\end{array}$ & $0.06(0.095)$ & $0.05(0.1012)$ & $0.04(0.1081)$ \\
\hline $\begin{array}{l}\text { Past armed conflict* } \\
\text { trust }\end{array}$ & $-0.06(0.074)$ & $-0.07(0.077)$ & $0.10(0.1146)$ \\
\hline
\end{tabular}

Note Estimation controls for variables: household size, per capita asset, age of household head, sex of household head, educational status of household head, household electrification status, enrolment of children and log amount of cultivated land. Social capital is used as control variable in specification 2 only

Robust standard errors in parentheses. $* * * p<0.01,{ }^{*} * p<0.05,{ }^{*} p<0.1$ 
variables, previous experience of armed conflict along with good relations among indigenous communities is highly statistically significant in increasing overall consumption (Table 8.2). A similar positive effect for non-food consumption exists for indigenous communities when land dispossession is interacted with intra-group trust.

Greater trust appears to effect household preferences about consumption. Moreover, the past actual experience of conflict is salient in this regard. In line with the arguments of Fehr and Hoff (2011), social institutions impact on individual preferences, implying that preferences are endogenous to social institutions and interactions. Conflict changes the nature of social interactions, local institutions and the constraints (social rules) that individuals face. The previous experience of conflict when combined with trust between different indigenous tribes appears to encourage consumption within that group. On the other hand, when trust factors are not taken into account, greater saving and less consumption is induced when there are apprehensions about future conflict, as well as previous experiences of armed conflict among both communities. Future fears of eviction raise consumption (significantly for Bengalis).

\subsubsection{School Enrolment}

Decisions to enrol children in school can be a proxy of investment decisions for the future, and because children are potentially suppliers of household labour, it entails an opportunity cost.

Our probit regression results of specification 1 in Table 8.3 indicate that current perceptions of violence fail to explain variations in the likelihood of children's enrolment as the coefficients are statistically insignificant. Although their relation is insignificant, households from both communities perceiving a danger of eviction have a greater chance of sending children to school compared to those households who do not have this perception, while apprehensions about armed conflict and communal violence recurring reduce the chance of child enrolment among the indigenous.

Past experiences of land dispossession have a deep-seated influence on current livelihood decision-making processes, which is evident in specification 2 in Table 8.3, particularly for the indigenous peoples. It shows that indigenous households having a previous experience of land dispossession have a higher probability of sending children to school as compared to those households who did not encounter this form of violence. The positive and statistically significant determining role of the experience of land dispossession is found robust across various estimation procedures (LPM, logit and probit). The experience of land dispossession is traumatic and creates long-standing vulnerabilities, as land is the most productive asset. This may raise the likelihood of sending their children to school, possibly with a view to overcoming the challenge of earning livelihoods from an ever-decreasing amount of cultivable land. But the primary 
Table 8.3 Determinants of child enrolment in school: probit estimation

\begin{tabular}{l|l|l}
\hline \multirow{2}{*}{ Independent variables } & \multicolumn{2}{l}{ Dependent variable: school enrolment } \\
\cline { 2 - 3 } & Indigenous household & $\begin{array}{l}\text { Bengali } \\
\text { household }\end{array}$ \\
\hline Specification 1: Current perception of violence & $0.01(0.051)$ \\
\hline Fear of armed conflict & $-0.01(0.040)$ & $0.01(0.042)$ \\
\hline Fear of communal violence & $-0.05(0.035)$ & $0.02(0.042)$ \\
\hline Fear of eviction from land & $0.003(0.034)$ & $0.05(0.054)$ \\
\hline Specification 2: Previous experience of violence & $0.04(0.042)$ \\
\hline Displacement from own home & $-0.05(0.045)$ & $0.05(0.046)$ \\
\hline Land dispossession & $0.09^{* *}(0.038)$ & \\
\hline Past armed conflict & $-0.02(0.034)$ &
\end{tabular}

Note Estimation controls for variables: age of child, age square of child, sex of child, household size, per capita asset, age of household head, sex of household head, educational status of household head, type of educational institutions, language of book and language of instruction. Social capital is used as control variable in specification 2 only

Robust standard errors in parentheses. $* * * p<0.01, * * p<0.05, * p<0.1$

'investment' motivation for schooling children is to allow future generations to acquire qualifications so that they may escape the conflict and are less dependent on agriculture.

\subsubsection{Production Decisions: Cropping Patterns}

Our regression results regarding determinants of cropping decisions are reported in Table 8.4. ${ }^{4}$ In the first specification, fear of communal violence has a positive and statistically significant role in raising the probability of mixed cropping (both food and cash crops) for both communities, which is statistically significant. There is a possible endogeneity between fear of communal violence and cropping decisions because households producing mixed crops might be more apprehensive, as this requires more fertile land in terms of location and other factors, and land is central to the conflict. We have used a variable describing overall satisfaction in social interactions in the community as a whole as an instrument since it is related to fears of future communal violence and not correlated to mixed cropping decisions. Durbin-Wu-Hausman tests of exogeneity show that there is no endogeneity problem, and it implies that the coefficient of the probit model is preferable to the IV probit. We also found our estimates robust across various models: LPM, logit and probit. The details can be found in Badiuzzaman et al. Cameron (2013).

\footnotetext{
${ }^{4}$ We do not have data on access to or distance from the market for each household in the survey, but because of the locations, the same distance from the market will apply to a large subsets of households surveyed.
} 
Table 8.4 Determinant of cropping decisions (mixed crop): probit estimation

\begin{tabular}{|c|c|c|}
\hline \multirow[t]{2}{*}{ Independent variables } & \multicolumn{2}{|c|}{ Dependent variable: mixed crop production } \\
\hline & Indigenous household & $\begin{array}{l}\text { Bengali } \\
\text { household }\end{array}$ \\
\hline \multicolumn{3}{|c|}{ Specification 1: Current perception of violence } \\
\hline Fear of armed conflict & $-0.03(0.057)$ & $0.07(0.074)$ \\
\hline Fear of communal violence & $0.14 * *(0.054)$ & $0.16^{* *}(0.063)$ \\
\hline Fear of eviction from own land & $0.00023(0.056)$ & $0.002(0.068)$ \\
\hline \multicolumn{3}{|c|}{ Specification 2: Previous experience of violence } \\
\hline Displacement from own home & $-0.06(0.055)$ & $0.04(0.069)$ \\
\hline Land dispossession & $-0.09 *(0.048)$ & $-0.03(0.056)$ \\
\hline Past armed conflict & $0.04(0.049)$ & $0.15 * *(0.062)$ \\
\hline \multicolumn{3}{|c|}{ Specification 3: Interaction of previous experience of violence and social capital } \\
\hline Displacement* trust & $-0.12(0.271)$ & $-0.64(0.5647)$ \\
\hline Land dispossession* trust & $0.27 *(0.132)$ & $-0.05(0.4564)$ \\
\hline Past armed conflict* trust & $0.27 *(0.147)$ & $0.71(0.5897)$ \\
\hline
\end{tabular}

Note Estimation controls for variables: household size, per capita asset, age of household head, sex of household head, educational status of household head, amount of cultivated land and type of cultivation techniques (jum, plough and both). Social capital is used as control variable in specification 2 only

Robust standard errors in parentheses. $* * * p<0.01, * * p<0.05, * p<0.1$

As per specification 1 of the probit estimation (Table 8.4), both indigenous and Bengali households perceiving fear of communal violence are found more likely to produce mixed crop and the result is robust across the linear probability, logit and probit models. Probit results under specification 2 show that previous experiences of armed conflict motivated Bengali households to engage in greater mixed cropping, and it is robust across linear probability and logit estimates. Earlier experiences of land dispossession lower the chances of mixed cropping among the indigenous population. The presence of trust (specification 3) significantly increases the probability of mixed cropping among the indigenous peoples when interacted with land dispossession and past armed conflict, but the same is found insignificant for Bengali settlers. A study on the conflict-affected parts of Northern Uganda by Rockmore (2012) suggests that conflict alters the composition of assets held towards less risky assets. Our findings are qualitatively similar to that of Nillesen and Verwimp (2010) for post-conflict rural Burundi, where the cultivation of cash crops also increased. In our case, the past experience of conflict and a fear of communal violence igniting in the future raise the probability of mixed crop production.

Our apparently anomalous results, with respect to rising risk-taking in cropping patterns following greater subjective feelings of violent experiences, can only be explained by less well-known theories about risky behaviour. Conventional wisdom would suggest that individuals become more risk averse after an adverse shock, such as conflict and the fear of violence. This is also the prediction of the expected utility theory in conjunction with the concavity property of standard 
utility functions leading to the properties of diminishing marginal utility of income, as well as absolute risk aversion. The standard precepts of expected utility do not, however, hold in many contexts. In our case, we can argue that both experience and subjective perceptions of violence amount to 'trauma', which has a pecuniary counterpart that may be characterised as one where the concerned individual or household has sustained a financial loss. Markowitz (1952) indicated that starting from a state of loss, individuals want to engage in more risk-taking to regain their previous valued position than when their wealth portfolio is exhibiting positive growth and their expectations are over-fulfilled. Second, he also pointed out that what may matter more for decisions to engage in risky projects is the distribution of the possible profit or loss it may entail rather than the absolute (expected) value of risky prospect. In other words, the direction of change in the household's asset position and the possibility of regaining a highly valued asset in monetary or social terms are more salient than its level in our case.

Following Kahneman and Tversky (1979), we may apply prospect theory to explain our empirical findings with regard to cropping patterns, bearing in mind that cash crop cultivation is more risky, as it does not guarantee the household's subsistence and is more subject to market fluctuations. Prospect theory represents a departure from expected utility in that it is a two-stage process, and risky ventures are weighted by not only (subjective) probability of the different risky states but also a more complicated 'decision weighting' process. The first stage of the decision involves an editing phase where a reference point is chosen to evaluate the likely effect of the actual risky investment framed in terms of specific aspects of the highly valued by the decision maker. This is akin to the framing decisions currently emphasised by behavioural economists and individual self-image stated much earlier by Boulding (1956). Following the trauma of eviction and/or violence, individuals may feel that the key value of assets has diminished and must be replaced as a priority. In the second stage of evaluation, when the household decides on its type of crop cultivation, it may take more risks, if the risky project has a high enough decision weight compared to the less risky alternative. Decision weighting is related to the probability of an uncertain project bearing fruition, but it also includes the subjective desirability of the outcome, a property that alters less readily in the mind than the pure probability of success. The point is that taking on more risks is understandable if there is a substantial chance that more risky investments will lead to recuperation of particular erstwhile losses. This may explain why households with a greater past experience of violence (and in some cases a fear of future conflict) are more likely to invest in the more risky cash crops along with food crops. ${ }^{5}$ Moreover, prospect theory also suggests that the

\footnotetext{
${ }^{5}$ Following Kahneman and Tversky (1979), let the value ( $V$ ) of the household's risky prospect be $V(x, y, p, L)=\pi(p, L) v(x)+[1-\pi(p, L)] v(y) \cdots \pi_{1}, \pi_{2}>0$. Here, $v(x)$ is the value of the risky project, $v(y)$ is the value of the less risky project, $p$ refers to the probability of success of $x$, and $\pi$ is the decision weight which is a positive function of both the probability of success and losses $(L)$ previously sustained. It is immediately apparent that an increase in losses due to perceptions of violence will raise the attractiveness of the risky project by weighing the decision more heavily in favour of $x$.
} 
decision weight given to a desirable outcome may be greater than its objective probability in the expected utility framework. In other words, individuals overweight the likelihood of a more desirable outcome.

Our results also have qualitatively similarities to the findings of Voors et al. (2012) in their field experiment in post-conflict Burundi, which indicate greater risk-taking and trust after conflict. While we only have data on trust for the survey period and are unable to infer any increase in trust, social capital in the form of trust could have a possible role in determining livelihood decisions, especially when it comes to certain consumption and cropping decisions among the indigenous peoples of CHT. In our case, the application of prospect theory to individual decision-making by households appears more salient when it comes to cropping decisions, especially among settler Bengali households, and seems better at explaining household risk-taking.

\subsection{Conclusions}

Our object has been to analyse household livelihood decision-making processes under the shadow of violence in the post-conflict CHT region of Bangladesh. As with other developing country internal conflicts, the accord ending the insurgency is imperfect in nature, and the central grievance concerning land encroachment is yet to be addressed. Violence between settlers who have encroached on the land of the ethnically distinct local population is still prevalent, and the Bangladesh army is still present in the region in substantial numbers to deal with any potential insurgency. Land, in the context of the densely populated and agriculturally dependent country, is the principal bone of contention. Thus, neo-Malthusian factors play a role in this conflict, as the shortage of land necessitates encroachment by settlers, which along with grievances induced by land grabbing and threats to the distinct way of life of the indigenous people produces conflict.

The main innovation of the analysis is the incorporation of psycho-social factors, specifically the trauma of past violence and also current perceptions of the likelihood of future conflict into the analysis of economic decision-making. We also include some information on trust between the different identities that make up the indigenous group in the region. In that sense, we endogenise preferences with regard to consumption, cropping and the decision to school children to these phenomena, in line with the tenets of current behavioural economics. Our research suggests that under certain circumstances, heightened subjective perceptions about violence reigniting in the future as well as past experiences of conflict may lower consumption expenditure as a risk-reducing tactic. The propensity to send children to school and engage in risky mixed crop cultivation may also increase with certain types of past experiences and future expectations of violence.

The endogenous determination of preferences is one aspect of the explanation for the phenomena we are observing. It cannot by itself adequately explain greater risk-taking. We go on to discover that certain types of risky behaviour are best 
explained by prospect theory, which under certain circumstances predicts a certain degree of risk-taking as a response to loss. While preferences may be endogenous to past experiences, current perceptions and social capital in the form of trust (behavioural economics), risk-taking can be better explained by prospect theory. Conflict (experienced or anticipated) may make some people bolder and more risk-taking in order to enhance their long-term future. Prospect theory is apposite in understanding this reaction, as people frame their decisions in the light of personal priorities that dominate the expected objective value of greater risk-taking.

Poverty and conflict are inextricably intertwined. The widespread presence of poverty enhances conflict risk; conflict equally inhibits poverty reduction; see Murshed (2010, Chaps. 2 and 3) for a literature review. Thus, it is important to diminish conflict risk in any strategy of poverty reduction, and conflict abatement also requires poverty reduction. An important policy consideration is, therefore, to reduce poverty in post-conflict settings, in particular; otherwise, conflict may reignite and poverty rise even further. A crucial corollary, at the local level, of this conclusion involves enhancing household-level economic activity immediately after the cessation of conflict. In addition to the standard poverty reduction prescriptions involving service provision (health, education and social services), skill acquisition and access to credit, an important facet of post-conflict reconstruction and poverty reduction is enhancing trust and confidence. This is the main policy conclusion of our study.

An extensive review of the literature on livelihoods in fragile and conflictaffected regions can be found in Malett and Slater (2012), suggesting a wide taxonomy of outcomes and mixed policy intervention success. Our results do suggest the possibility of a post-conflict Phoenix or rapid economic recovery factor at the household level in the CHT region of Bangladesh. Its presence or absence has a lot to do with individual household behaviour, and the manner in which past experiences of violence and current perceptions about future conflict are processed in the mind. If it makes individuals bolder so they aim at recovering past losses, or local institutional settings induce a preference for greater investment, a Phoenix factor may ensue, and rapid growth may follow. In this connection, the presence or absence of positive social capital may assist in greater investment for the future and enhanced poverty reduction. In addition to the standard prescriptions for poverty reduction, involving increased access to credit and skill acquisition and microcredit, our study demonstrates the salience of confidence building. Ultimately, much hinges on confidence. Here, local factors in decision-making are salient, but a lot will still depend on the macropolitical and economic framework for largescale recovery to take place.

Acknowledgments We are grateful to the European Union FP 6 MICROCON research project for financial help, and the CHTDF-UNDP in Bangladesh who funded the household survey analysed in this paper and gave us permission to use the same data set. 
Open Access This chapter is distributed under the terms of the Creative Commons Attribution Noncommercial License, which permits any noncommercial use, distribution, and reproduction in any medium, provided the original author(s) and source are credited.

\section{References}

Addison T, Murshed SM (2005) Post-conflict reconstruction in Africa: some analytical issues. In: Collier P, Fosu A (eds) Post-conflict reconstruction in Africa. Palgrave, London, pp 3-17

Badiuzzaman M, Cameron J, Murshed SM (2013) Livelihood decisions under the shadow of conflict in the Chittagong Hill Tracts of Bangladesh, UNU/WIDER working paper no. 2013/006. http://www.wider.unu.edu/publications/working-papers/2013/en_GB/wp2013-006/

Banerjee A, Iyer L (2005) History, institutions and economic performance: the legacy of colonial land tenure systems in India. Am Econ Rev 95(4):1190-1213

Bardhan P, Udry C (1999) Development microeconomics. Oxford University Press, New York

Barkat A et al (2009) Socio-economic baseline survey of Chittagong Hill Tract. CHTDF-UNDP, Dhaka

Boulding KE (1956) The image: knowledge in life and society. University of Michigan Press, Ann Arbor

Bowles S (1998) Endogenous preferences: the cultural consequences of markets and other economic institutions. J Econ Lit 36(1):75-111

Chakma SS (2006) Ethnic cleansing in the Chittagong Hill Tracts. Ankur Prakashani, Dhaka

Collier P (2007) The bottom billion: why the poorest countries are failing and what can be done about it. University Press, Oxford

Fehr E, Hoff K (2011) Tastes, castes and culture: the influence of society on preferences, policy research paper, working paper 5760, The World Bank

Homer-Dixon TF (1999) Environment, scarcity, and violence. Princeton University Press, Princeton

Kahneman D, Tversky A (1979) Prospect theory: an analysis of decision under risk. Econometrica 47(2):263-292

Koubi V (2005) War and economic performance. J Peace Res 42(1):67-82

Malett, R. \& Slater, R. (2012) Growth and livelihoods in fragile and conflict-affected situations, working paper 9, secure livelihoods and research consortium, Overseas Development Institute, UK

Markowitz H (1952) The utility of wealth. J Polit Econ 60(2):151-158

Mohsin A (2003) The Chittagong Hill Tracts of Bangladesh on the difficult road to peace. Lynne Rienner Publishers Inc, London

Murshed SM (2010) Explaining civil war: a rational choice approach. Edward Elgar, Cheltenham

Murshed SM, Gates S (2005) Spatial-horizontal inequality and the maoist conflict in Nepal. Rev Devel Econ 9(1):121-134

Nillesen E, Verwimp P (2010) A phoenix in flames? Portfolio choice and violence of civil war in rural Burundi, UNU-wider working paper 2010/44

Rockmore M (2012) Living within conflicts: risk of violence and livelihood portfolios, HiCN working paper 121, www.hicn.org/wordpress/wp-content/uploads/2012/06/HiCN-WP121.pdf (Accessed 06 Nov 2013)

Roy RC (2000) Land rights of the indigenous peoples of the Chittagong Hill Tracts, Bangladesh. IWGIA, Copenhagen

Voors MJ, Nillesen EEM, Bulte EH, Lensink BW, Verwimp P, van Soest DP (2012) Violent conflict and behavior: a field experiment in Burundi. Am Econ Rev 102(2):941-964

World Bank (2010) World development report 2010: development and climate change, The World Bank, Washington DC 